\title{
Kenozoické sedimenty v lomu Předklášteří u Tišnova
}

\author{
Cenozoic sediments in the Předklášteří u Tišnova Quarry
}

\section{Oldřich Krejčí ', Miroslav Bubík', David Buriánek', Nela Doláková2, Vladimíra Krejčí ', Slavomír Nehyba ${ }^{2}$, Pavla Tomanová Petrová' $\square_{\rightarrow}$, Jan Vít ${ }^{1}$}

'Česká geologická služba, Leitnerova 22, 60200 Brno, ČR

2 Ústav geologických věd PřF MU, Kotlářská 2, 61137 Brno, ČR

Key words:

Carpathian Foredeep, sedimentology, geochemistry, paleontology, translucent heavy minerals, landslide, mining

$\curvearrowleft$ pavla.petrova@geology.cz

Editor:

Martin Ivanov

\begin{abstract}
In the multi-level quarry Předklášteři near Tišnov exploiting medium-grained biotite metagranite of the Brunovistulicum, up to $30 \mathrm{~m}$ thick unconsolidated sediments, were studied recently at the top of excavation. These sediments are exposed at the two top quarry levels. During the exploration work in 1965, these sediments were not encountered, because today's quarry mining area has already exceeded the original considerations about the extent of mining.

The altitude of the erosive base of these fluvial or deltaic sediments 370-375 $\mathrm{m}$ indicates their pre-Quaternary age. Our research was focussed on the Lower Miocene part of the sediments tentatively considered as lake, delta or river sediments. Sediments were studied by sedimentological, petrographic, mineralogical, geochemical and paleontological methods. Preliminary results from overlaying Quaternary sediments did not allow definite stratigraphical interpretation.

Geochemical analyses of silty clays to claystones were compared with the occurrences of similar sediments from Brno and its surroundings (Kamechy, Kohoutovice, Obrany, Svinošice). These analyses proved that the sediments underwent a short transport of several kilometres and could be derived from weathering residues of the rocks forming the surrounding Brunovistulicum.

Our research has confirmed the affiliation of sediments in top of the sequence to the Pleistocene colluvial deposits. Sediments found in the lower part of the layered sequence, trapped along the fault of the $E-W$ direction, were assigned stratigraphically to the Lower Miocene (Ottnangian).
\end{abstract}

\section{Úvod}

Během posledních několika let došlo $\mathrm{v}$ rozsáhlém aktivním lomu firmy KÁMEN Zbraslav, a. s., v provozovně v Předklášteří, k odkrytí komplexu sedimentů s předpokládaným rozsahem kvartérního stáří s možným přesahem do období miocénu. Tyto sedimenty byly s postupujícím rozsahem těžby zastiženy při j. okraji dobývacího prostoru lomu, mimo plochu původního ložiskového průzkumu (Grym a Žůrek 1965). Průzkumné práce zahrnovaly celkem 14 vrtů s hloubkami od $33 \mathrm{~m}$ do 113,5 m. Protože v roce 1965 nebyl předpokládán dnešní rozsah těžby, vrty byly situovány prakticky na skalním podkladu, pouze nejjižnější vrt V-3 prošel $12 \mathrm{~m}$ kvartérního pokryvu.

V době detailního geologického mapování České geologické služby v měřítku 1 : 25 000, které probíhalo na listu mapy 24-321 Tišnov zejména v roce 2000 (Hanžl, ed. 2007a), nebyly tyto sedimenty odkryty. V lomu se těží středně 
zrnité biotitické metagranity, převážně chloritické, které jsou součástí svrateckého masivu. Směr a sklon foliace hornin skalního podkladu kolísá: 242-272/40-60. Lom byl založen ve strmém skalním svahu se sklonem do $25^{\circ}$ v rozpětí nadmořských výšek 260 až $380 \mathrm{~m}$. Dnešní hrana lomu dosahuje výšky $390 \mathrm{~m}$ n. m. a není vyznačena v aktuálním mapovém díle ČR ZABAGED ${ }^{\circledR}$ V rozpětí 380-390 m n. m. se v původním reliéfu nacházela plošina

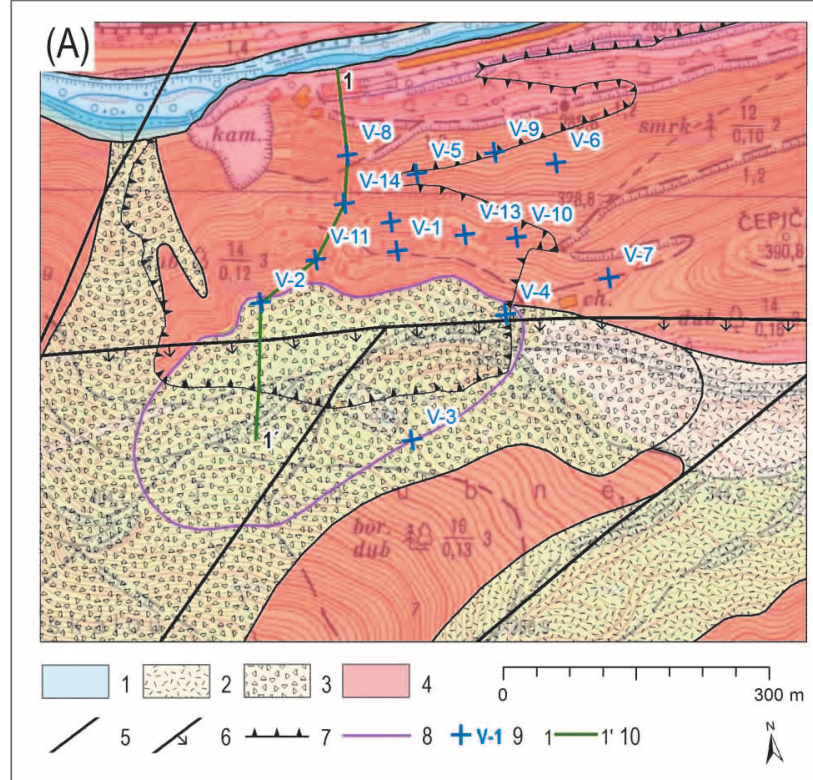

(C)

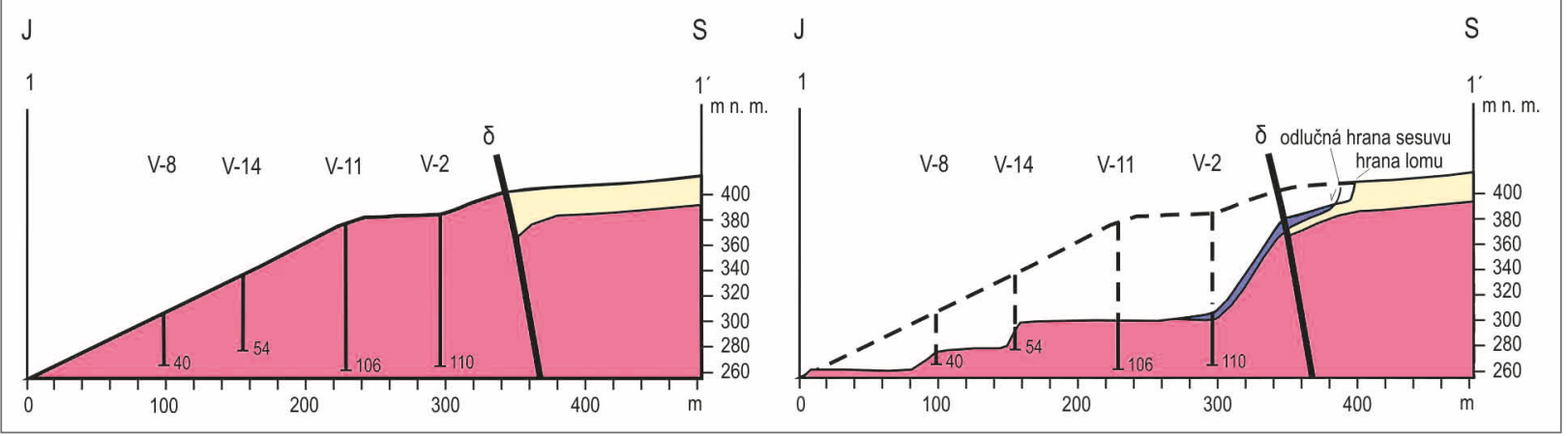

Obr. 1: (A) Geologická mapa území okolí lomu před rozšířením těžby (rok 1952) v topografickém podkladu systému S-1952 s vynesenými průzkumnými vrty. Podklad je podle ČÚZK Praha. Legenda: 1 - fluviální hlinitopísčité sedimenty; 2 - hlinitokamenité svahové sedimenty; 3 - hlinitokamenité až blokové svahové sedimenty; 4 - biotitický metagranit; 5 - zlom; 6 - zlom s pokleslou krou; 7 - současný okraj aktivního lomu; 8 - rozsah zakrytých pleistocenních až neogenních sedimentů; 9 - průzkumný vrt; 10 - linie geologického řezu. (B) Geologická mapa území okolí lomu v digitálním topografickém podkladu systému ZABAGED ${ }^{\circ}$ s vynesenými průzkumnými vrty. Podklad je podle ČÚZK Praha. Legenda: 1 - navážky; 2 - fluviální hlinitopísčité sedimenty; 3 - hlinitokamenité svahové sedimenty; 4 - hlinitokamenité až blokové svahové sedimenty; 5 - pleistocenní až neogenní sedimenty; 6 - sesouvané sedimenty a bloky skalního podkladu; 7 - biotitický metagranit; 8 - zlom; 9 - zlom s pokleslou krou; 10 - směr a sklon foliace; 11 - současný okraj aktivního lomu; 12 - rozsah zakrytých pleistocenních až neogenních; 13 - průzkumný vrt; 14 - linie geologického řezu. (C) Geologický řez 1-1'prostorem lomu s původním reliéfem před rozvojem těžby s vyznačenými průzkumnými vrty. Bez holocenního pokryvu. (D) Geologický řez 1-1'prostorem lomu se současným reliéfem terénu. Původní reliéf je vyznačen čárkovaně. Bez holocenního pokryvu.

Fig. 1: (A) Geological map of the area around the quarry before the expansion of mining (year 1952) in the topographic base of the S-1952 system with exploratory wells. Background is according to ČÚZK Praha. Legend: 1 - fluvial sediments (sandy loam); 2 - gravitational sediments (loamy gravel); 3 - gravitational sediments (loamy gravel with blocks); 4 - biotitic metagranite; 5 - fault; 6 - normal fault; 7 - current edge of the active quarry; 8 - range of covered Pleistocene to Neogene sediments; 9 - exploratory well; 10 - geological section line. (B) Geological map of the quarry area in the digital topographic base of the ZABAGED ${ }^{\circledR}$ system with exploratory wells. Background is according to ČÚZK Praha. Legend: 1 - landfills; 2 - fluvial loam-sandy sediments; 3 - loam-stone slope sediments; 4 - loam-stone to block-slope sediments; 5 - Pleistocene to Neogene sediments; 6 - sediments and rock blocks in landslides; 7 - biotitic metagranite; 8 - fault; 9 - normal fault; 10 - direction and slope of foliation; 11 - current edge of the active quarry; 12 - range of covered Pleistocene to Neogene sediments; 13 - exploratory well; 14 - geological section line. (C) Geological section 1-1'in the quarry area with the original relief before the expansion of mining with marked exploratory boreholes. No Holocene cover. (D) Geological section 1-1'in the quarry area with the current relief. The original relief is marked with dashed lines. No Holocene cover. 
(obr. 1A, C), kde je pod vrstvou holocenních svahových kamenitohlinitých sutí, mocných do $1,5 \mathrm{~m}$, v současnosti odkrytý komplex sedimentů, který byl předmětem našeho zkoumání (obr. 1B, D). Na okraji plošiny s těmito sedimenty jsme zdokumentovali zlom směru Z-V se strmým sklonem, podél něhož jsou ty to sedimenty zaklesnuty, a tím došlo $\mathrm{k}$ jejich zachování. Dnešní zarovnaná báze fosilní plošiny je 370-375 m n. m. Sedimenty ještě pokračují pod její úroveň $\mathrm{v}$ menších zaklesnutých kapsách do úrovně přibližně $10 \mathrm{~m}$ pod její bázi. Celková maximální mocnost zachovaných sedimentů může činit až $30 \mathrm{~m}$. V nejmladších fázích geologického vývoje pak došlo k překrytí holocenními až svrchnopleistocenními svahovými sedimenty. V těchto sedimentech byly identifikovány i přemístěné sprašové hlíny se zbytky půd, jejich původní stratigrafická pozice nebyla již zjistitelná.

Protože tyto nadložní sedimenty nemají praktické využití, jsou v z. části lomu řízeně sesouvány k patě svahu (obr. 2a). K tomuto sesouvání byl využit sesuv ve střední části lomu, kde došlo vlivem clonových odstřelů k sesunutí bloků skalního podkladu i s nadložními sedimenty. Odlučné hrany sesuvu se v jeho horních patrech i nadále vyvíjejí a dochází tak stále k propadům reliéfu lomu.

Předmětem naší práce byl mikropaleontologický, sedimentologický, petrografický a geochemický výzkum na lokalitě Předklášteří, jehož hlavním cílem bylo stratigrafické zařazení sedimentů předpokládaného miocenního stárí a srovnání s výskyty podobných uloženin v blízkém okolí.

\section{Geologická situace}

Spodnopleistocenní fluviální písčité štěrky leží na listu 24-321 Tišnov v úrovni kolem $45 \mathrm{~m}$ nad současným tokem řeky Svratky (Hanžl, ed. 2007a). Nadmořská výška báze uložení většiny nejstarších námi zkoumaných písčitých až štěrkovitých sedimentů 370 až $375 \mathrm{~m} \mathrm{n}$. m. ukazuje na to, že se jedná o uloženiny předkvartérní. Obecně se za nejvyšší terasový stupeň, odpovídající současnému systému vodních toků na rozhraní pliocén/pleistocén, považuje stránská terasa (Musil 1993). Na Stránské skále v Brně byla zjištěna v nadmořských výškách 253-255 m ( 60 m nad úrovní dnešního toku Svitavy). Úroveň námi studovaných sedimentů je o více než 50 m vyšší (hladina Svratky je 260 m n. m.). Pliocenní regionálně sledovatelná terasa líšeňská má v Brně a okolí výšku nad mořem $\sim 298$ m, relativně leží do $100 \mathrm{~m}$ nad současnými hlavními toky (Musil 1997). Námi studované sedimenty jsou i nad touto úrovní, která zde odpovídá $360 \mathrm{~m}$ n. m. Obdobné, převážně písčité a štěrkovité sedimenty s menším podílem písčitých jílů bývají v širším okolí řazeny obvykle do ottnangu (Hanžl, ed. 2007a). Protože jejich původ je fluviální a deltový, neobsahují autochtonní mořskou mikrofaunu. Zpravidla jsou stratigraficky zařazovány podle litologického složení, sedimentologických charakteristik, asociací těžkých minerálů a redepozic kř́ídové mikrofauny (Hlavoňová 1977; Petrová et al. 2001; Nehyba et al. 2006; Hanžl, ed. 2007a). V některých př́padech jsou známy i sedimenty jezerní se slojkami uhlí (Smetana 1924), dokumentované nově např. ve vrtu 2242_2 Hradčany (Burda a Novotná 2015). Průvodním jevem tohoto období ve spodním miocénu bývá kaolinizace krystalinického podloží (Smetana 1924), a především jílovitá až jemně písčitá sedimentace má bělošedé a červenohnědé odstíny (Tomanová Petrová et al. 2018). Sedimenty ottnangského stáří v okolí mají zjištěné mocnosti ve vrtu VO-2-15 na sv. okraji Vohančic do 60 m (Lázničková a Pokorný 2016) a ve vrtu 2242_2 v Hradčanech 50,2 m (Burda a Novotná 2015).

Starší eggenburgská mořská transgrese z oblasti karpatské předhlubně, ani mladší marinní sedimenty ottnangu, nejsou z území na S od Brna známy. V blízkosti se nachází pouze plošně omezený relikt mořských sedimentů karpatu (Petrová et al. 2001; Hanžl, ed. 2007b). Křídové redepozice jsou charakteristické pro sedimenty ottnangu v okolí Brna, zatímco v karpatských marinních sedimentech nebyly zaznamenány. Možný výskyt kř́idových redepozic je v sedimentech badenu na S od Předklášteří v Bělči (Bubík 1997). Tyto sedimenty byly původně považovány za relikt sedimentů křídy (Šamalíková 1992). Badenské sedimenty jsou však prakticky vždy mořského původu, který lze mikropaleontologicky doložit, a tvoří souvislý výskyt v tektonicky zaklesnutém údolí mezi Tišnovem a Doubravníkem (Brzák 2000; Vít et al. 2017).

\section{Materiál a metodika}

Studované vzorky byly odebrány $\mathrm{z}$ různých litofaciálních asociací. Horninové analýzy dvou studovaných vzorků (TP-1: 6/19 a 2/20) byly provedeny metodou ICP-MS v laboratořích Acme Analytic Laboratories Ltd., Vancouver, Kanada. Studované horninové analýzy byly zpracovávány pomocí programu GCDKit (Janoušek et al. 2006).

Valounová analýza, provedená na dokumentačním bodu Dl04 (10/20), byla realizována na materiálu o zrnitosti 1 až $6 \mathrm{~cm}$ a celkově bylo zpracováno 276 horninových klastů. Klasty jiné velikosti se v odkryvu nevyskytovaly.

Za účelem mikropaleontologického studia bylo odebráno celkem 8 vzorků z dokumentačních bodů ČGS (d. b.) TP-1, D102 a Dl04. Poté byla hornina namočena do roztoku jedlé sody a plavena na sítě o velikosti ok $0,063 \mathrm{~mm}$. Mikrofosílie z výplavů byly zkoumány a identifikovány pod optickými mikroskopy. Pro palynologické studium bylo odebráno celkem 7 vzorků: 2 vzorky z horní etáže, 3 z ronové rýhy na bázi horní etáže, 2 z jílovitých proplástků ve vrstvě s pískem (delta?).

Palynomorfy byly ze sedimentů získány macerací za pomoci $10 \% \mathrm{HCl}$ (24 hod.) a $30 \% \mathrm{HF}$ (2 dny). Obsah palynomorf a ostatních organických částic byl koncentrován pomocí těžké kapaliny $\mathrm{ZnCl}_{2}\left(2 \mathrm{~g} / \mathrm{cm}^{3}\right)$. Mikroskopické studium vzorků bylo prováděno optickým mikroskopem Nikon Alphaphot 2.

Ze zkoumaných profilů (d. b. TP-1 a Dl04) byly odebrány i vzorky na analýzu asociací průsvitných těžkých minerálů. Vzorky byly separovány $\mathrm{v}$ těžké kapalině LST za zvýšené teploty (hustota 2,96 g/ml). Vyseparovaná zrna průsvitných těžkých minerálů (PTM) byla určena $\mathrm{v}$ polarizačním mikroskopu. Zastoupení zrn bylo vyjádřeno 


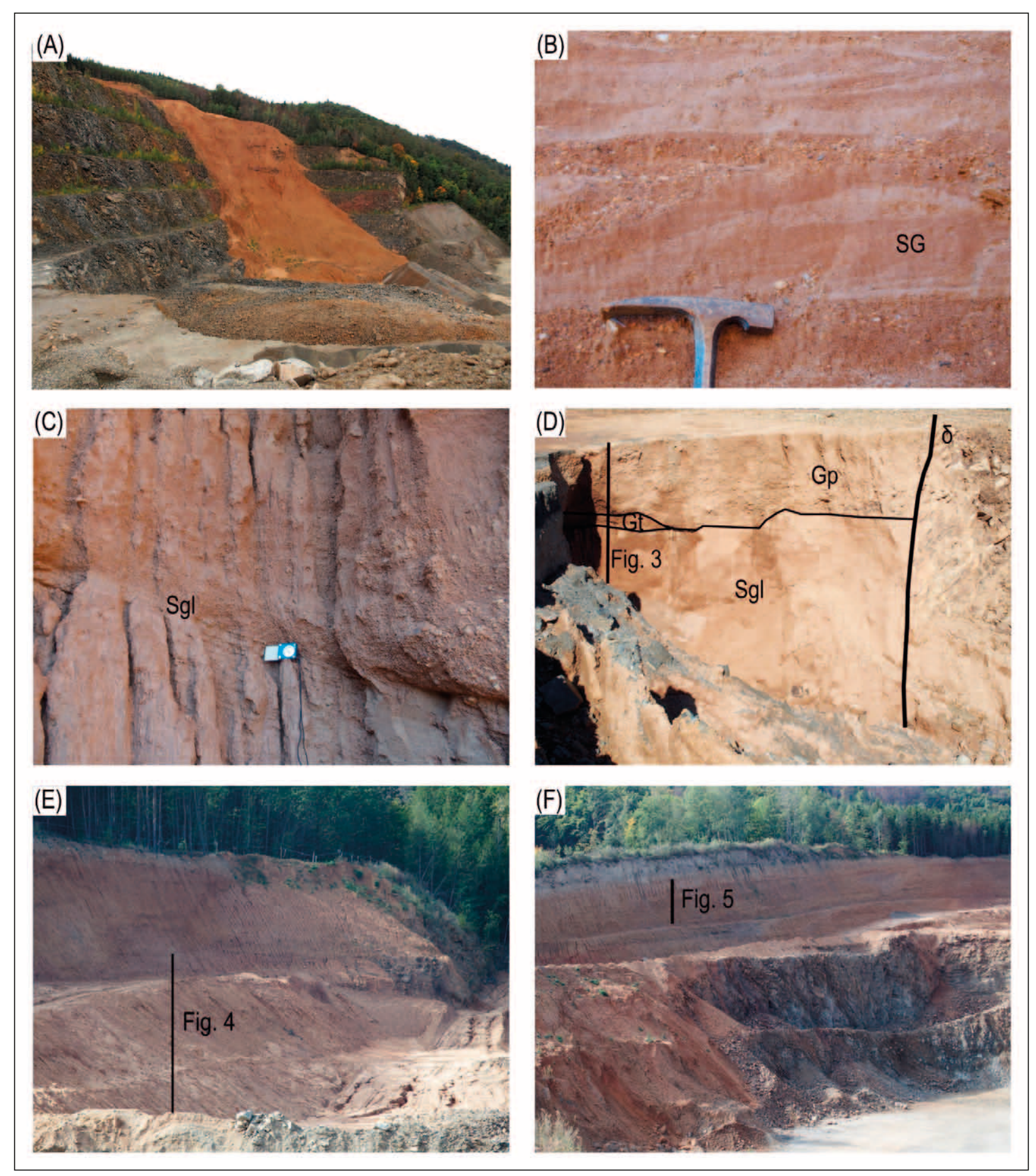

Obr. 2: (A) Zemní proud přes jednotlivé etáže lomu, který představuje řízený transport nevyužitelné skrývky mimo těžební oblast. (B) detailní pohled na štěrkovitopísčité sedimenty litofacie SG. (C) kontakt písčitých sedimentů s jemnozrnnými štěrky v nadloží (vše Sgl). (D) spodní část studovaného sedimentárního sledu, zaklesnutá podél zlomu směru Z-V. Je vyznačen kontakt mezi štěrkovými sedimenty litofacie Gp a jemnozrnějšími sedimenty litofacie Sgl a litofaciální asociace FA1 (obr. 3). (E) nejvyšší část lomu. Vpravo v popředí je odlučná hrana zemního proudu. Linie představuje rozsah faciální asociace FA2 (obr. 4). (F) celkový pohled na nejvyšší část lomu. V nejvyšší části jsou světlé holocenní hlinitokamenité sedimenty. Linie představuje rozsah litofaciální asociace FA3 (obr. 5).

Fig. 2: (A) Earth current through the individual benchs of the quarry, which represents the controlled transport of unusable spoil outside the mining area. (B) detailed view of gravel-sandy sediments of lithofacies SG. (C) contact of sandy sediments with underlying fine-grained gravels (all Sgl). (D) the lower part of the studied sedimentary profile, locked along the fault, W-E direction. The contact between gravel sediments of the lithofacies $\mathrm{Gp}$ and finer-grained sediments of the lithofacies Sgl and the extent of the lithofacial association FA1 (Fig. 3) are indicated. (E) the highest part of the quarry. To the right in the foreground is a main scarp of the earthcurrent. The line represents the extent of the facial association FA2 (Fig. 4). (F) general view on the highest part of the quarry. In the highest part there are light Holocene loam-stone sediments. The line represents the extent of the facial association FA3 (Fig. 5). 
v modálních procentech jednotlivých minerálů nebo jejich skupin.

\section{Výsledky a interpretace Sedimentologie a petrografie}

Litofaciální studium sedimentů v rámci odkryvu neogenních a kvartérních sedimentů vedlo k identifikaci 9 litofacií. Jejich popis a základní interpretace jsou obsaženy v tabulce 1 .

Litofacie byly následně sestaveny do tří faciálních asociací (FA), tj. uskupení prostorově a geneticky př́ibuzných facií, které odráží dílčí depoziční prostředí.

\section{Faciální asociace 1 - sedimenty komplexní výplně fluviálního koryta}

Tato faciální asociace je tvořena především mocně vrstevnatými (1,0-1,9 m mocnými) sedimenty facií Gp $(59,4 \%)$ a $\operatorname{Sgl}(23,4 \%)$ - obr. 2d. Podřízeně jsou prítomny středně mocně vrstevnaté $(0,25-0,5 \mathrm{~m}$ mocné) sedimenty facií Sp (5,7 \%), St (6,5\%) a facie Gt (4,0 \%). Litologický profil FA1 je znázorněn na obrázku 3.

Bazální facie Sgl je interpretována jako odraz poproudové migrace rozsáhlého písčitého valu s dobře vyvinutou poproudovou stranou (př́íný val? - Bridge
1993; Jo and Chough 2001; Scherer et al. 2014). Paleoproudění ukazuje na víceméně konzistentní transport směrem k S či SZ. Migrace po proudu, pozice poblíž kontaktu s podložním krystalinikem a ostrý přechod do nadložních sedimentárních facií Gt a Gp mohou ukazovat na poproudovou akreci v rámci spodních partií složeného fluviálního valu (compound bar) s množstvím naložených valů (Allen 1983; Haszeldine 1983; Wizevich 1992; Miall 1996) a rychlé zaplňování nerovného podloží. Sedimenty facií Gt a Gp odrážejí tvorbu štěrkových valů s lineárním či zvlněným průběhem hřbetu ( $t j$. $2 \mathrm{D}$ a $3 \mathrm{D}$ valy). Sedimenty litofacií Sp a St ukazují na tvorbu relativně drobnějších písčitých valů, které nejspíše migrovaly po tělesech štěrkových valů nebo mezi nimi za nižšího vodního stavu. Jednotlivá mocnější tělesa štěrku, oddělená méně mocnými tělesy písku s obdobnými typy zvrstvení, lze vysvětlit rozdíly v průtočném množství a rychlosti vodního proudu v rámci koryta, kdy mohlo docházet k částečné modifikaci štěrkových valů. Tyto procesy mohou odrážet klimatické změny, případně určitá překládání koryt (avulze) výše proti proudu. Víceméně deskovité šikmo zvrstvené sety a cosety lze spojit s migrací dílčích sedimentárních těles (subakvatické valy), které vykazují vertikální akreci společně s migrací směrem

Tabulka 1: Popis a základní interpretace litofacií na lokalitě Předklášteří.

Table 1: Description and basic interpretation of lithofacies in the Předklášteří locality.

\begin{tabular}{|c|c|c|}
\hline Symbol & Popis & Interpretace \\
\hline Sgl & $\begin{array}{l}\text { Světle šedý jemnozrnný štěrkovitý písek, planární šikmé zvrstvení velké škály, relativně stabilní } \\
\text { sklon zvrstvení ca } 25^{\circ} \text { i jeho směr (nezjištěna báze). Nebyly pozorovány vnitřní erozní/reaktivační } \\
\text { povrchy. Velmi špatné vytřídění díky prítomnosti psefitické frakce, protáhlé klasty někdy oriento- } \\
\text { vány osou A rovnoběžně s vrstevnatostí. Granule a drobné valouny do } 5 \mathrm{~mm} \text {, obvykle subangu- } \\
\text { lární až angulární. Mocnost vrstev kolem } 150 \mathrm{~cm} \text {, vrstvy mají klínovitý a deskovitý tvar, laterální } \\
\text { rozsah nad } 5 \mathrm{~m} \text {. Angulární ostrá báze, ostrá nerovná svrchní vrstevní plocha (obr. } 2 \mathrm{~d} \text { ). }\end{array}$ & $\begin{array}{l}\text { Sedimentace } \mathrm{v} \text { rámci foresetů } \\
\text { subakvatických } 2 \mathrm{D} \text { valů na } \\
\text { značně ukloněném povrchu, } \\
\text { rychlá depozice, př́ípadná role } \\
\text { gravitačních proudů }\end{array}$ \\
\hline Gt & $\begin{array}{l}\text { Štěrk s podpůrnou strukturou valounů až podpůrnou strukturou písčité matrix, korytovité šikmé } \\
\text { zvrstvení, špatně vytříděný. Psefitické klasty obvykle do } 3 \mathrm{~cm} \text {, ojediněle až } 10 \mathrm{~cm} \text {, subangulární } \\
\text { až angulární. Mocnost jednotlivých setů do } 20 \mathrm{~cm} \text {, coset do } 1 \mathrm{~m} \text { mocný. Nahoru zjemnjující trend } \\
\text { v rámci setů. Ostrá erozní konkávní báze, ostrý erozní planární top (obr. 2b). }\end{array}$ & $\begin{array}{l}\text { Subakvatické 3D štěrkové valy } \\
\text { (Rust 1978; Todd 1996). }\end{array}$ \\
\hline Gp & $\begin{array}{l}\text { Štěrk s podpůrnou strukturou valounů až podpůrnou strukturou písčité matrix, planární šikmé } \\
\text { zvrstvení, špatně vytříděný. Subangulární, angulární i zaoblené valouny obvykle do } 7 \mathrm{~mm} \text {, vzácně } \\
\text { až } 20 \mathrm{~cm} \text {. Nahoru zjemňující trend. Nepravidelně deskovité těleso, mocnost do } 120 \mathrm{~cm} \text {. Nepravi- } \\
\text { delná ostrá erozní konkávní i planární báze, ostrý planární top. }\end{array}$ & $\begin{array}{l}\text { Subakvatické 2D štěrkové valy } \\
\text { (Rust 1978; Todd 1996). }\end{array}$ \\
\hline St & $\begin{array}{l}\text { Velmi hrubozrnný písek s příměsí granulí a valounů do } 4 \mathrm{~mm} \text {, korytovité šikmé zvrstvení, špatně } \\
\text { vytř́iděný. Erozní relikt o mocnosti do } 40 \mathrm{~cm} \text {, erozní nerovná báze i svrchní vrstevní plocha. }\end{array}$ & $\begin{array}{l}\text { 3D písčité valy, spodní proudový } \\
\text { režim, subakvatická depozice }\end{array}$ \\
\hline $\mathrm{Sp}$ & $\begin{array}{l}\text { Proměnlivě vytříděný hrubozrnný písek, planární šikmé zvrstvení. Ukloněná deskovitá vložka } \\
\text { v rámci štěrkových facií, mocnosti do } 30 \mathrm{~cm} \text {. Ostrá planární báze i top. }\end{array}$ & $\begin{array}{l}\text { 2D písčité valy, subakvatická } \\
\text { depozice, spodní proudový režim }\end{array}$ \\
\hline SG & $\begin{array}{l}\text { Střídání nepravidelných } 5-20 \mathrm{~cm} \text { mocných relativně hrubozrnnějších poloh tvořených velmi } \\
\text { hrubozrnným pískem s valouny až drobnozrnným štěrkem (valouny do } 3 \mathrm{~cm} \text {, zaoblené, poloza- } \\
\text { oblené i subangulární) s podpůrnou strukturou písčité matrix a nepravidelných } 5-30 \mathrm{~cm} \text { mocných } \\
\text { relativně jemnozrnnějších poloh tvořených špatně vytříděným jemnozrnným až střednozrnným } \\
\text { pískem. Jednotlivé dílčí polohy mají nepravidelně klínovitý či čočkovitý tvar, typické jsou ostré } \\
\text { báze i top dílčích poloh, které mohou být konvexní či konkávní, či nepravidelně planární. Relativ- } \\
\text { ně jemnozrnnější písčité polohy vykazují obvykle ukloněnou nebo horizontální planární laminaci, } \\
\text { výrazně vzácnější je čeřinové šikmé zvrstvení. Relativně hrubozrnnější polohy jsou planárně či } \\
\text { korytovitě šikmo zvrstvené, případně masivní. V rámci jemnozrnnějších poloh občasné izolované } \\
\text { valouny do } 2 \mathrm{~cm} \text {. }\end{array}$ & $\begin{array}{l}\text { Střídání podmínek vyššího } \\
\text { proudového režimu a podmínek } \\
\text { nižšího proudového režimu } \\
\text { v rámci dominantní role plošné- } \\
\text { ho splachu / štítový tok. }\end{array}$ \\
\hline $\mathrm{Gm}$ & $\begin{array}{l}\text { Štěrk s podpůrnou strukturou valounů, masivní až hrubé planární/horizontální zvrstvení. Na bázi } \\
\text { valouny až } 30 \mathrm{~cm} \text {, zjemňování směrem vzhưru. Protáhlé valouny orientovány osou A rovnoběžně } \\
\text { se zvrstvením. Mocnost deskovitých těles do } 50 \mathrm{~cm} \text {, ostrá erozní planární báze s nevýrazným } \\
\text { reliéfem, konvexní či plochý ostrý top. }\end{array}$ & $\begin{array}{l}\text { Trakční sedimenty z plochých } \\
\text { štěrkových valů (Hein, Walker } \\
\text { 1977; Lloret et al. 2018) }\end{array}$ \\
\hline $\mathrm{Mg}$ & $\begin{array}{l}\text { Světle hnědá, rezavě i žlutavě smouhovaná hlína s izolovanými klasty až do } 30 \mathrm{~cm} \text { (osa A). Hrubě } \\
\text { ukloněná planární zvrstvení. Klasty jsou většinou subangulární a angulární, lokální provenience. } \\
\text { Střídání ca } 20-25 \mathrm{~cm} \text { mocných poloh relativně bohatších psefitickými klasty, kde klasty leží často } \\
\text { ploše, rovnoběžně s vrstevnatostí a ca } 40-50 \mathrm{~cm} \text { mocných poloh jen s občasnými psefitickými } \\
\text { klasty. Mocnost nad } 4 \mathrm{~m} \text {, ukloněné deskovité těleso, úklon generelně k SV-V. Ostrá báze. }\end{array}$ & $\begin{array}{l}\text { Kvartérní deluviofluviální } \\
\text { sedimenty (aluviální kužel) - } \\
\text { sedimenty hustých gravitačních } \\
\text { proudů. }\end{array}$ \\
\hline Go & $\begin{array}{l}\text { Deskovitá poloha ostrohranného štěrku a podpůrnou strukturou klastů. Subangulární až angulár- } \\
\text { ní klasty, max. velikost nad } 50 \mathrm{~cm} \text {. Ukloněné deskovité těleso o mocnosti max. několika klastů. }\end{array}$ & Trakční sedimenty \\
\hline
\end{tabular}




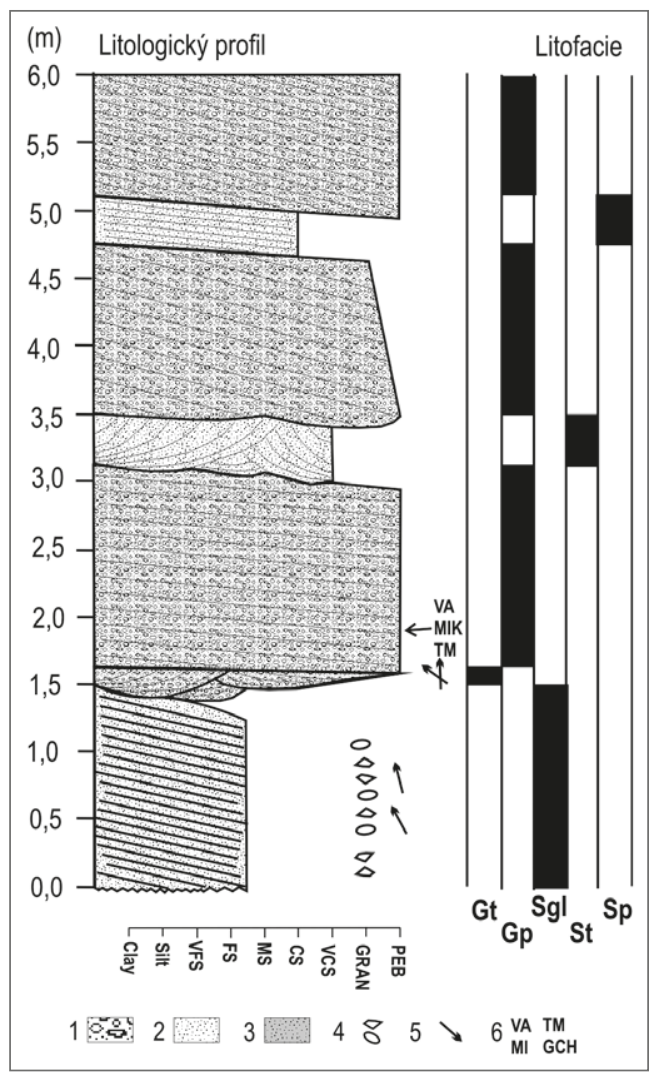

Obr. 3: Litologický profil se zobrazením litofacií faciální asociace FA1. Legenda pro obrázky 3-5: 1 - štěrk; 2 - písek; 3 - jílovitý písek; 4 - valouny; 5 - orientace šikmého zvrstvení; 6 - vzorky VA: valounová analýza; MIK: mikroskopie; GCH: geochemie; TM: průsvitné těžké minerály. VFS: velmi jemnozrnný písek; FS: jemnozrnný písek; MS: středozrnný písek; CS: hrubozrnný písek; VCS: velmi hrubozrnný písek; GRAN: granule; PEB: valouny.

Fig. 3: Lithological profile with depiction of lithofacies of the facial association FA1. Legend for Fig. 3-5: 1 - gravel; 2 - sand; 3 - clayey sand; 4 - scattered pebles; 5 - orientation of cross-stratification; 6 - VA: samples for gravel analyses; MIK: samples for micropaleontological study; GCH: samples for whole geochemical analyses; TM: samples for translucent heavy minerals analyses. VFS: very fine sand; FS: fine sand; MS: medium sand; CS: coarse sand; VCS: very coarse sand; GRAN: granules; PEB: pebbles.

po proudu (Miall 1996). 3D valy by mohly ukazovat na relativně hlubší části koryt než 2D valy (Bristow 1987; Miall 1994; Jo and Chough 2001). Šikmo zvrstvené štěrky a hrubozrnné písky ukazují na transport v rámci vodního proudu, který byl v rámci koryta schopen transportovat hrubozrnné částice, formovat štěrkové valy vykazující nejspíše především migraci po proudu za podmínek spodního proudového režimu (Ashley 1990).

Komplikovaně složená (multistorey) architektura sedimentárního tělesa, dominantně hrubozrnný charakter sedimentů, relativní stabilita paleoproudových dat, chybějící evidence jemnozrnných sedimentů i nahoru zjemňujících cyklů a převaha poproudově akretujících sedimentárních těles signalizují nízkou sinuositu koryt, tedy jejich relativně př́mý průběh. Ukloněný deskovitý tvar písčitých a štěrkovitých těles může indikovat rychlá, vysoce mobilní fluviální koryta (Friend 1983). Naprostá

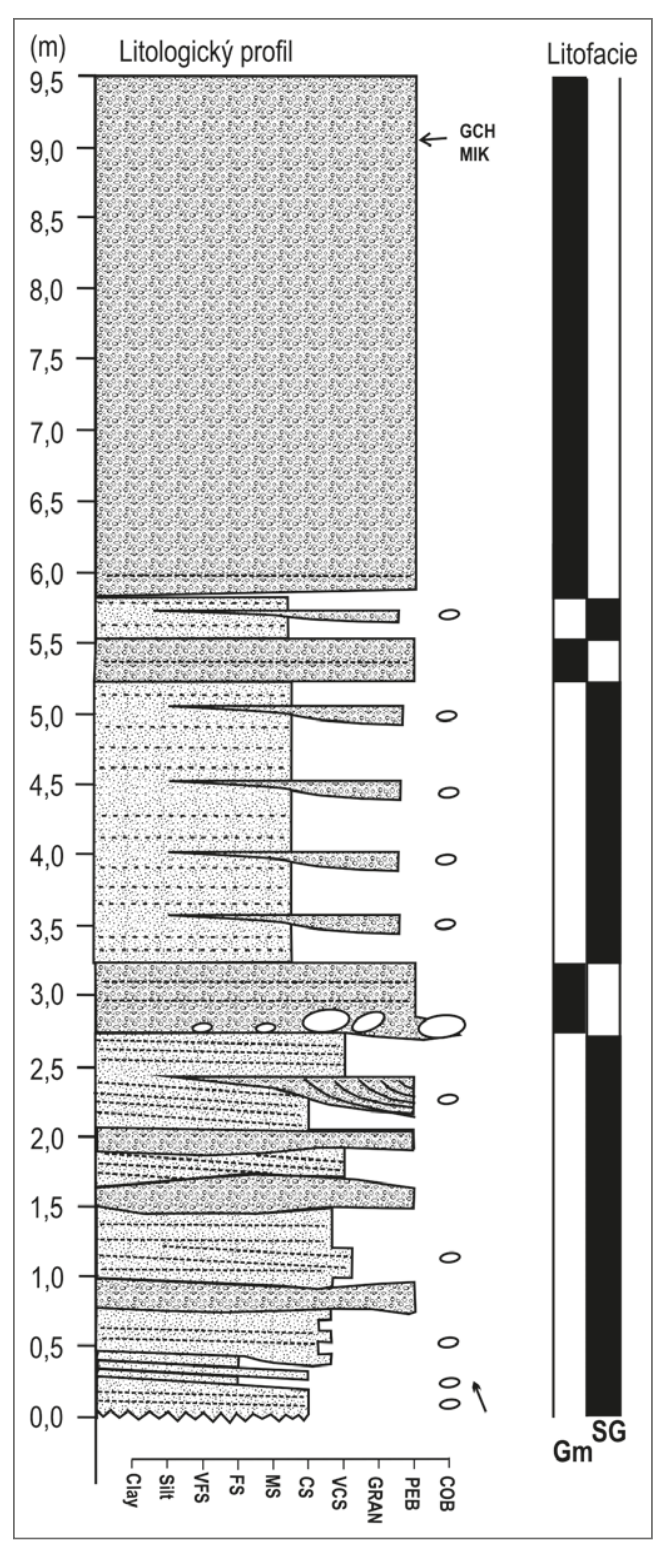

Obr. 4: Litologický profil se zobrazením litofacií faciální asociace FA2.

Fig. 4: Lithological profile with depiction of lithofacies of the facial association FA2.

dominance šikmého zvrstvení naopak ukazuje na relativně konstantní průtok a stabilitu koryta (Miall 1996; Allen et al. 2013).

Bezprostřední kontakt nejnižších partií profilu s podložními krystalickými horninami nebyl odkryt, nachází se přibližně $30-50 \mathrm{~cm}$ pod bází profilu I. V bočních stěnách nepravidelné deprese byl však zachycen kontakt facií Sgl a Gp s podložními metagranity. Sedimenty profilu I tedy nejspíše vyplňují nepravidelnou depresi s šíŕkou nad $15 \mathrm{~m}$ a hloubkou více než $7 \mathrm{~m}$. Existence deprese vedla nejspíše k určité prostorové stabilizaci koryta a sedimentace (confined deposits).

\section{Faciální asociace 2 - sedimenty mediální části aluviálního kužele (obr. 2e)}

Střední část profilu byla popsána ve vyšší těžební etáži v nadloží FA1. Samotný kontakt FA1 a FA2 není 
odkryt. Neogenní sedimenty FA2 jsou odkryty jako plošně rozsáhlé (šírka nad $200 \mathrm{~m}$, mocnost nad $7 \mathrm{~m}$ ) nepravidelně deskovité až klínovité těleso, které je ploše erozně seř́iznuto a přikryto nadložními kvartérními sedimenty (FA3). Sedimenty FA2 lze označit jako relativně málo pozičně stabilizované (unconfined deposits). Faciální asociace 2 je dominantně $(80 \%)$ tvořena tence až silně vrstevnatými (0,25-2,50 m mocnými) sedimenty facie SG a dále $(20 \%)$ také tence až středně mocně vrstevnatými (0,25-0,50 m mocnými) sedimenty facie Gm. Litologický profil FA2 je znázorněn na obrázku 4.

Ploše deskovité až 2,5 m mocné sedimenty litofacie SG jsou relativně jemnozrnnější (než facie FA1). Výskyt planární laminace, čeřinového zvrstvení i šikmého zvrstvení s menším sklonem lamin signalizují trakční sedimentaci z proudů s relativně nižším množstvím transportovaného materiálu. Čočkovitá a klínovitá geometrie a polohy hrubozrnnějších štěrků, často s korytovitou bází, odpovídají sedimentaci z relativně mělkých a obvykle i níže energetických vodních proudů, než v případě FA1. Tyto se vyskytovaly nejspíše na tělese aluviálního kužele, kde docházelo k přepracování opuštěných nebo neaktivních částí kužele (Went 2005). Chybějící evidence bahenních prasklin a jemnozrnných prachovito-jílovitých sedimentů nepodporuje predstavu o periodickém vystavení terénu působení atmosféry a byly tedy zjištěny především subakvatické sedimenty. Sedimenty litofacie SG jsou interpretovány jako sedimenty z vodních proudi̊, částečně nejspíše charakteru štítových toků (sheetflood). Paleoproudění ukazuje na transport směrem k SZ. Špatné vytřídění je nejspíše projevem př́valového charakteru sedimentů. Lze předpokládat, že vodní proudy měly značně nižší kompetenci než proudy ve spodní části sedimentárního sledu (FA1), př́ípadně další proudy fungující na tělese kužele (facie $\mathrm{Gm}$ ). Opakovaně vyvinuté sety facie Gm v rámci mocnějších těles facie SG jsou interpretovány jako výplně koryt, které brázdily povrch aluviálního kužele. Chybějící šikmé zvrstvení ukazuje na neexistenci migrujících štěrkových valů v rámci koryt. Tělesa facie Gm signalizují výrazně hrubší koryta, než jaká jsou spojována s existencí čočkovitých těles štěrků v rámci facie SG. Náznaky přednostního uspořádání klastů spolu s horizontální stratifikací naznačují selektivní depozici a pravděpodobně přívalový charakter s dominancí materiálu transportovaného trakcí. Subhorizontální stratifikace je interpretována jako odraz depozice $\mathrm{z}$ relativně mělkých, ale dynamických proudů s proměnlivou energií.

Výskyt těchto sedimentů ve vyšších partiích sedimentárního sledu ukazuje, že se může jednat také o distálnější části aluviálního kužele nebo dílčí drobnější kužel. Stř́íání facie SG a Gm indikuje, že tyto neaktivní či distální části kužele byly opakovaně zasaženy hlubšími a širšími vodními koryty s velmi nízkou amplitudou. Lze předpokládat rychlou sedimentaci

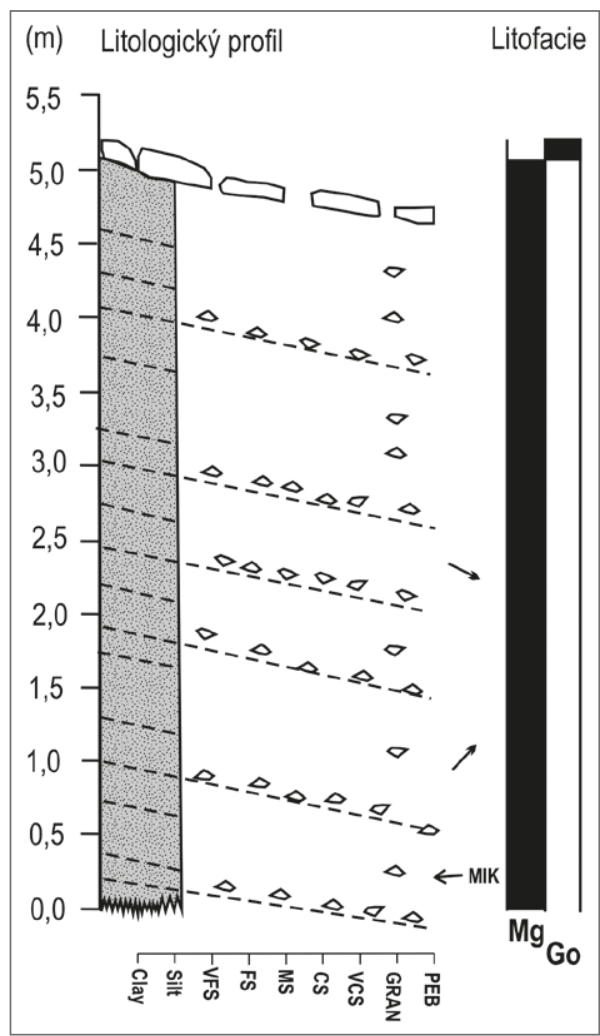

Obr. 5: Litologický profil se zobrazením litofacií faciální asociace FA3.

Fig. 5: Lithological profile with depiction of lithofacies of the facial association FA3.

a dostatek zvětralin ve zdrojové oblasti. Na tělese kužele nebyl dokumentován výskyt vegetace. Vývoj laterálně amalgamovaných štítových těles, prostorově spojených s výplní koryt, lze vysvětlit opakovanou avulzí koryt, takže opětovně docházelo k přepracování starších sedimentů, což vysvětluje relativně vyšší prrítomnost zaoblených psefitických klastů v rámci FA2 než v případě FA1 a také chybějící zachování mimokorytových sedimentů (Mackey a Bridge 1995; Miall 1996; Bridge 2003; Gibling 2006).

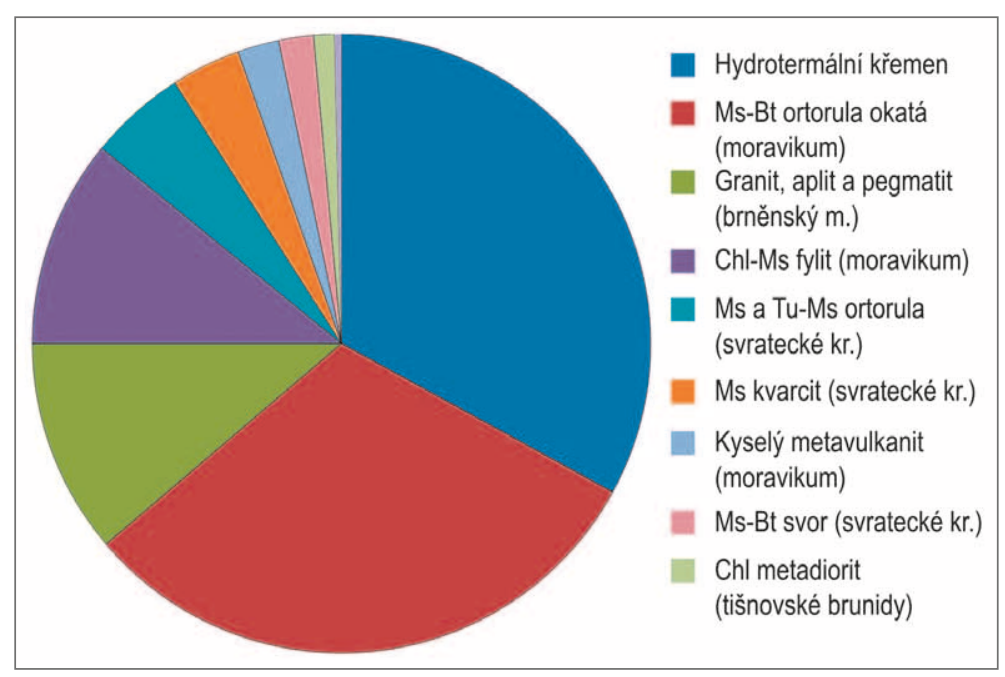

Obr. 6: Grafy valounové analýzy pro zrnitostní frakci 1 až $6 \mathrm{~cm}$. Fig. 6: Clast petrology diagram for the grain fraction 1 to $6 \mathrm{~cm}$. 


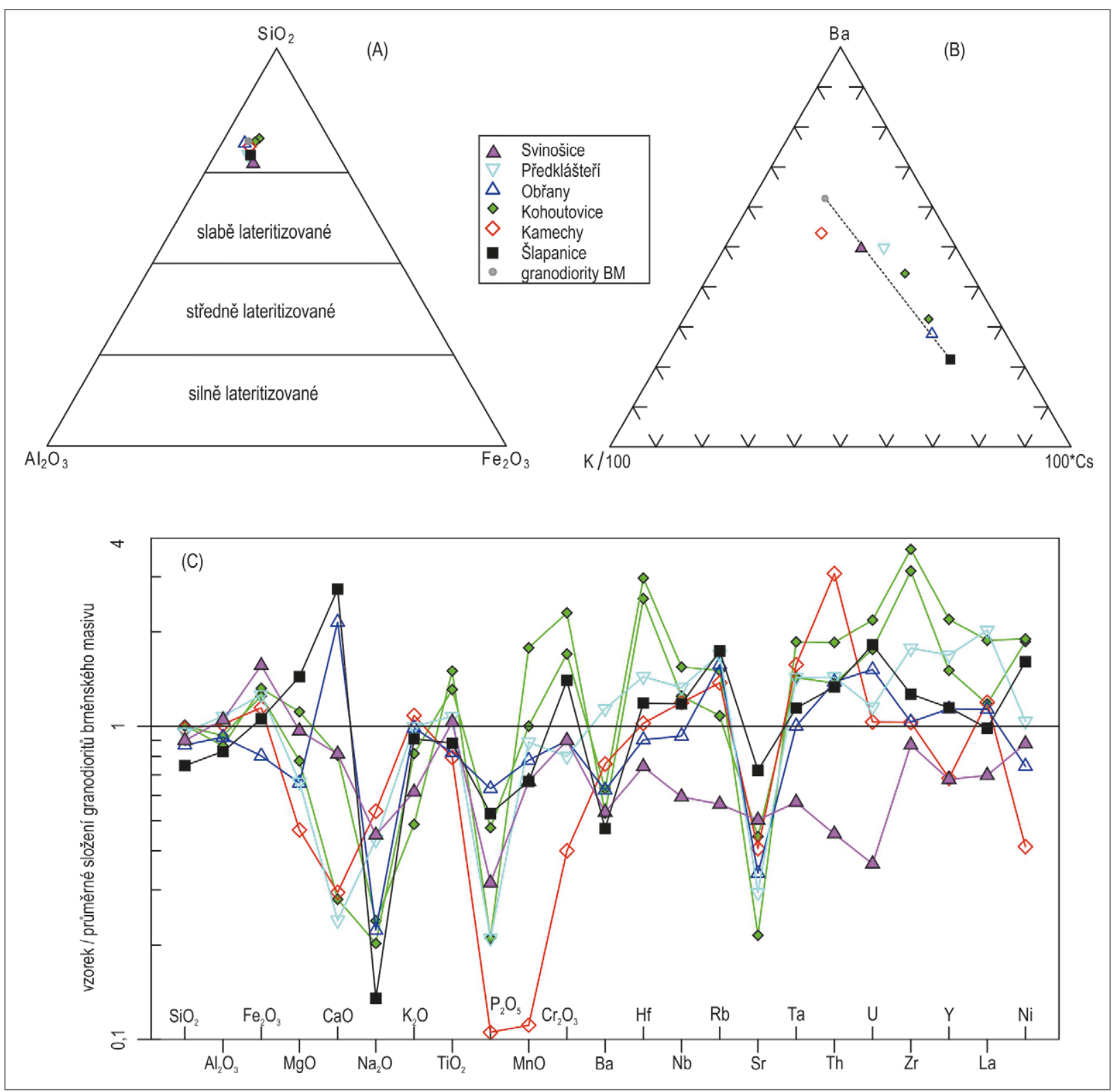

Obr. 7: Chemické složení studovaných hornin v lomu Předklášteří u Tišnova a na dalších studovaných lokalitách: (A) ternární diagram $\mathrm{Al}_{2} \mathrm{O}_{3}-\mathrm{SiO}_{2}-\mathrm{Fe}_{2} \mathrm{O}_{3}$ (wt. \%) pro laterity podle klasifikace Schellmanna (1983), (B) ternární diagram $\mathrm{K} / 100-\mathrm{Ba}-\mathrm{Cs}^{\star} 100$, (C) vybrané prvky ze sedimentů normalizované PGB (Gürtlerová et al. 1997).

Fig. 7: Chemical composition of studied rocks in the Předklášteří u Tišnova quarry and in the other localities under study: (A) ternary diagram $\mathrm{Al}_{2} \mathrm{O}_{3}-\mathrm{SiO}_{2}-\mathrm{Fe}_{2} \mathrm{O}_{3}$ (wt. \%) for laterite based on Schellmann (1983) classification. (B) ternary diagram K/100-Ba$\mathrm{Cs}^{\star} 100$, (C) selected elements from studied sediments normalized to PGB (Gürtlerová et al. 1997).

Faciální asociace 3 - kvartérní sedimenty aluviálního kužele (obr. 2f)

Faciální asociace 3 tvoří nejvyšší části sedimentárního sledu a byla zjištěna v nadloží FA2. Tato asociace je tvořena především sedimenty litofacie $\mathrm{Mg}$ a dále sedimenty facie Go. Litologický profil FA3 je znázorněn na obrázku 5.

Subhorizontální zvrstevní a přednostní uspořádání rozptýlených hrubších klastů v rámci facie $\mathrm{Mg}$ lze interpretovat jako odraz sedimentace z relativně hustých gravitačních proudů se silnou rolí laminárního proudění a smykového namáhání (Rees 1968). Tyto proudy lze spojit s kohezivními úlomkotoky (Lowe 1982). Sedimenty litofacie Go jsou interpretovány jako produkty valení a krátkého přemístění zvětralých úlomků z lokálních okolních elevací (debris fall). Určitou roli mohlo také sehrát následné přepracování tekoucí vodou, které vedlo k tvorbě stratifikace (Nemec a Kazanci 1999). Střídání partií relativně bohatších a chudších na hrubé klastické úlomky psefitické frakce $\mathrm{v}$ rámci facie $\mathrm{Mg}$, podobně jako stř́ídání litofacie Mg a Go, lze nejspíše spojit s rozdílnou intenzitou a mechanismem zvětrávání ve zdrojové oblasti a také rozdílným množstvím tekoucí vody v rámci depozičního prostředí, což vedlo k jinému mechanismu transportu materiálu po svahu. Tyto rozdíly bývají obvykle vysvětlovány jako produkt sezónních/klimatických změn v rámci kvartéru (Blikra, Nemec 1998). Kvartérním sedimentům nebyla dále věnována bližší pozornost. 


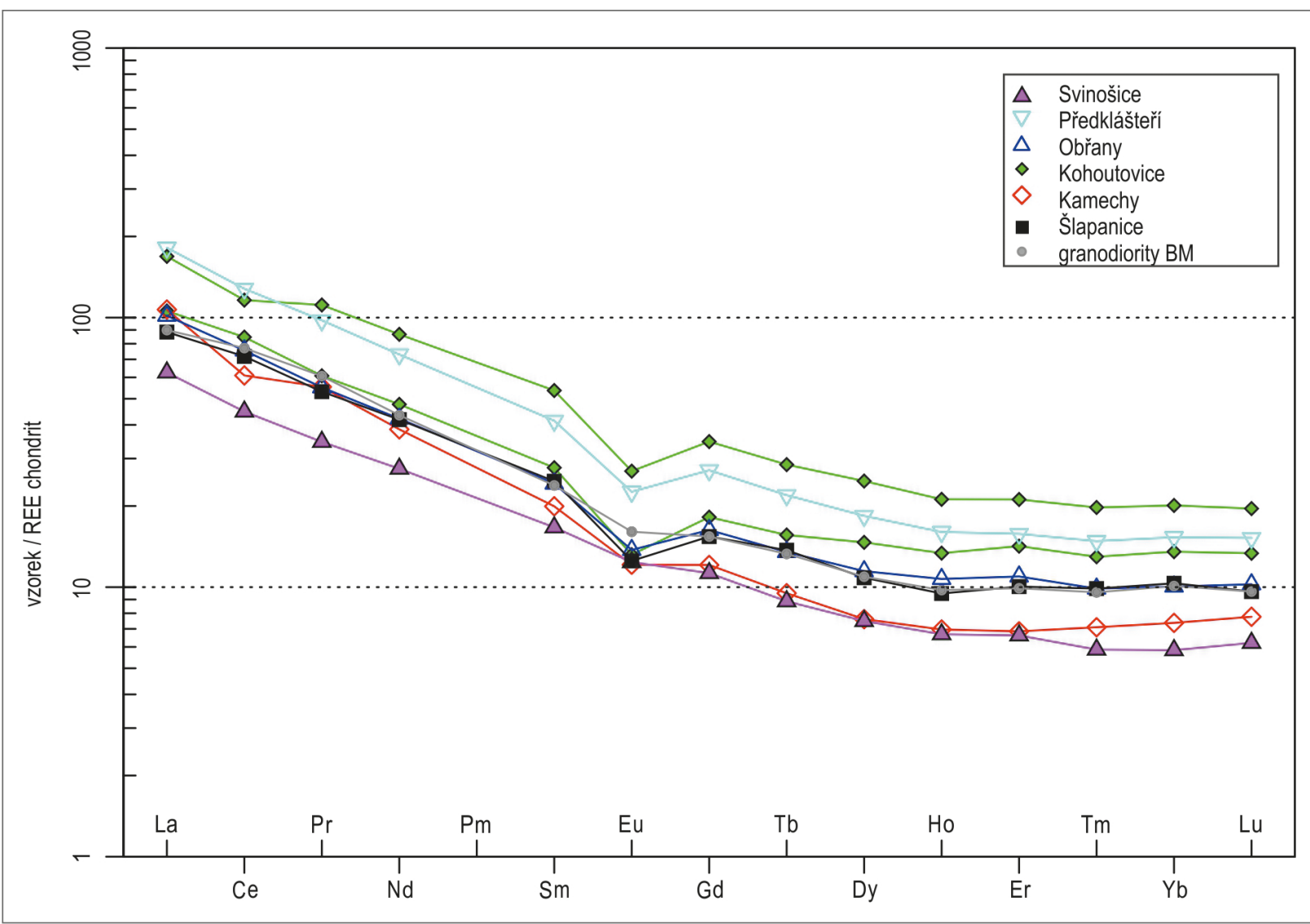

Obr. 8: Obsahy REE normalizované chondritem (Boynton 1984).

Fig. 8: Variation in REE normalized to chondrite (Boynton 1984).

\section{Valounová analýza}

Valounová analýza naznačuje, že klastický materiál pocházel převážně z blízkého okolí (obr. 6; Elektronická příloha A). Dominují valouny hydrotermálního křemene (33\%) a muskovit-biotitických ortorul s porfyroblasty živců (30,8\%). Tyto ortoruly svým vzhledem připomínají bítešskou ortorulu z moravika. Ze stejné jednotky také pocházejí chlorit-muskovitické fylity (11,2\%) a kyselé metavulkanity (2,2\%). Muskovit-biotitické granity, aplit a pegmatit pravděpodobně pocházejí z brněnského masivu. Původ klastů muskovitických a turmalín-muskovitických ortorul ( 5,1\%), muskovitických kvarcitů $(\sim 3,6 \%)$ a muskovit-biotitických svorů $(\sim 1,8 \%)$ lze pravděpodobně hledat ve svrateckém krystaliniku. Relativně málo klastů pochází z podložních hornin tišnovských brunid ( 1,1 \%). Př́itomen je také limonit a to v množství $0,4 \%$.

\section{Geochemická charakteristika}

Nově analyzovaný sediment z lomu Předklášteří u Tišnova (d. b. TP-1a) má chemické složení charakterizované vysokým obsahem $\mathrm{SiO}_{2}\left(61,88 \mathrm{hm}\right.$. \%) a $\mathrm{Al}_{2} \mathrm{O}_{3}(16,58$ hm. \%). Zmíněný vzorek byl srovnán $s$ výsledky dvou analýz sedimentů ottnangského stáří, které nebyly dosud publikovány (Elektronická příloha B): Svinošice (d. b. SV01) a Kamechy (d. b. BP389). Dále byl použit vzorek sedimentu z lokality Obřany (d. b. BP367 - ottnang; Hanžl, ed. 2020) a dva vzorky sedimentů ottnangského stáří z lokality Kohoutovice (Tomanová Petrová et al. 2018). Tři zmíněné sedimenty leží na granitoidech (Kamechy,
Obřany, Předklášteří) a jeden na bazických a ultrabazických horninách dioritové zóny brněnského masivu (Svinošice). Jako srovnávací materiál pro určení stupně zvětrávání studovaných sedimentů byly použity jeden vzorek spodnobadenského jílu z cihelny ve Šlapanicích (d. b. BP112; Tomanová Petrová, ed. 2013) a průměrné složení ze 42 vzorků granitoidů z brněnského masivu (PGB; zdrojová data pocházejí z databáze ČGS; Gürtlerová et al. 1997).

Ve srovnání s PGB vykazují všechny studované sedimenty vyšší poměry $\mathrm{K}_{2} \mathrm{O} / \mathrm{Na}_{2} \mathrm{O}(0,74$ vs. $1,01-3,26)$ a $\mathrm{Al}_{2} \mathrm{O}_{3} / \mathrm{SiO}_{2}(0,24$ vs. $0,25-0,28)$. Složení spodnobadenského jílu z cihelny ve Šlapanicích naopak vykazuje hodnotu $\mathrm{K}_{2} \mathrm{O} / \mathrm{Na}_{2} \mathrm{O}$ vyšší $(4,98)$ než studované vzorky, zatímco poměr $\mathrm{Al}_{2} \mathrm{O}_{3} / \mathrm{SiO}_{2}$ má srovnatelnou hodnotu se vzorkem sedimentu ottnangu z Obřan $(0,26)$. Podle klasifikace Schellmanna (1983) se nejedná o laterity (obr. 7a). V trojúhelníkovém diagramu K/100-Ba-100*Cs jsou studované vzorky distribuovány podél spojnice mezi PGB a spodnobadenským jílem z cihelny ve Šlapanicích (obr. 7b).

Obsahy vybraných hlavních a stopových prvků ve čtyřech studovaných vzorcích byly normalizovány hodnotou PGB (Gürtlerová et al. 1997), z čehož jsou patrné hlavní rozdíly mezi jednotlivými vzorky (obr. 7b). Sediment ze Svinošic vykazuje ve srovnání se složením PGB mírně zvýšené obsahy oxidu $\mathrm{Fe}_{2} \mathrm{O}_{3}, \mathrm{TiO}_{2}, \mathrm{Al}_{2} \mathrm{O}_{3}$. Vzorek $\mathrm{z}$ Předklášteří se naproti tomu vyznačuje zvýšenými obsahy HFS prvků (high-field-strength elements) 


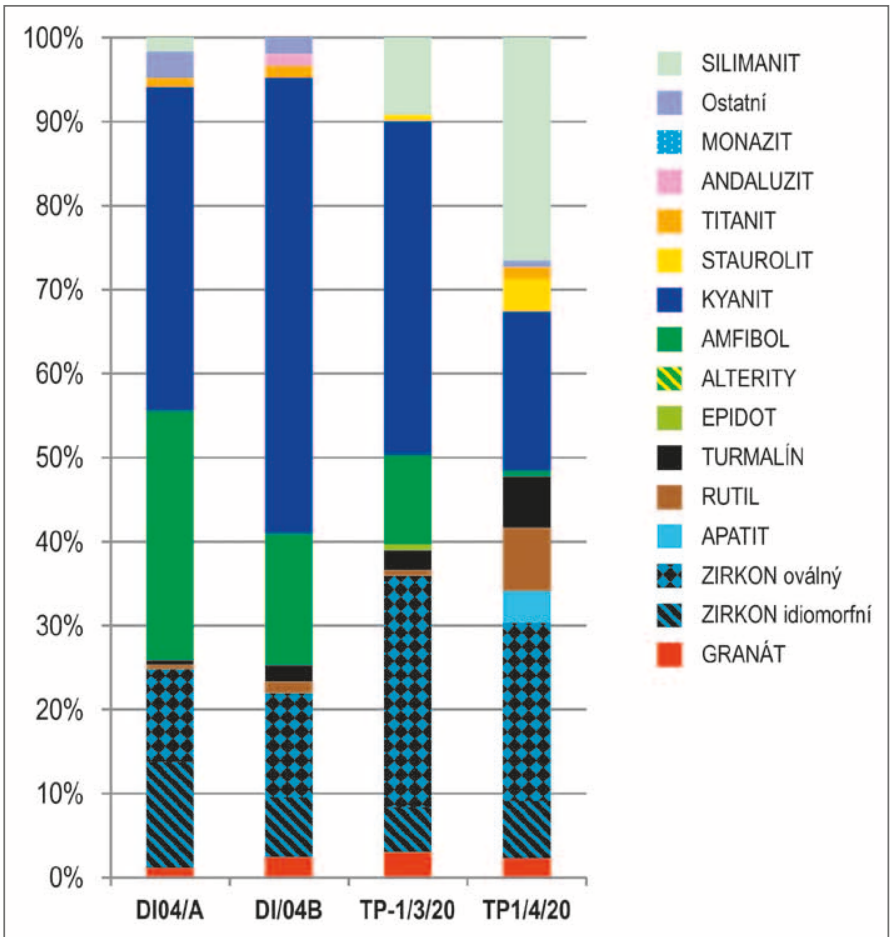

Obr. 9: Analýza průsvitných těžkých minerálů ze vzorků Dl04 a TP-1, Předklášteří.

Fig. 9: Analysis of translucent heavy minerals from the samples Dl04 and TP-1, Předklášteří.

a nízkými hodnotami $\mathrm{Sr}, \mathrm{P}_{2} \mathrm{O}_{5}$, CaO. Vzorek z lokality Obřany se vyznačuje vysokým obsahem $\mathrm{CaO}$ a nízkými obsahy $\mathrm{Na}_{2} \mathrm{O}, \mathrm{P}_{2} \mathrm{O}_{5}$, Ba a Sr. Sediment z lokality Kamechy se od předchozích liší především vyšším obsahem Th a nízkými obsahy $\mathrm{P}_{2} \mathrm{O}_{5}, \mathrm{MnO}, \mathrm{Ni}$.

Studované vzorky sedimentů mají podobné tvary normalizovaných křivek vzácných zemin, které vykazují nevýraznou zápornou $\mathrm{Eu}$ anomálii $\left(\mathrm{Eu} / \mathrm{Eu}^{*}=0,67-0,90\right)$ a obohacení LREE $\left(\mathrm{La}_{\mathrm{N}} / \mathrm{Yb}_{\mathrm{N}}=10,1-14,5\right)$. Jednotlivé vzorky se liší celkovými obsahy REE (90-248; obr. 8). Tvary křivek REE všech studovaných vzorků sedimentů se podobají granodioritům a spodnobadenskému jílu $\mathrm{z}$ cihelny ve Šlapanicích (obr. 8). Celkové obsahy REE se pohybují kolem hodnoty vypočtené pro PGB (153 ppm), přičemž suma REE pro vzorek $z$ lokality Předklášteří je vyšší, zatímco sumy REE z lokalit Obřany, Kamechy a Svinošice jsou nižší (Elektronická př́loha B).

\section{Paleontologie}

Ve vzorku TP-1 [litofacie a faciální asociace Gp (FA1), Gm (FA2) a Mg (FA3)] bylo zjištěno společenstvo aglutinovaných foraminifer a ojedinělá jehlice houby. Mikrofauna představuje patrně pseudoasociaci-kompletně přeplavenou mikrofaunu v mladých, pravděpodobně miocenních sedimentech. Dominují úlomky Rhizammina cf. algaeformis B., dále byly zjišstěny druhy Hyperammina sp., Haplophragmoides porrectus M., H. kirki W., Spiroplectammina navarroana (C.), S. cf. praelonga (R.), Karrerulina conversa (G.) a Dorothia sp. juv.

Z paleoekologického hlediska jde o mikrofaunu hlubokomořskou (batyál). Stratigrafické rozpětí druhů je velké nebo v některých př́padech dosud přesně nezjištěné.
V každém př́ípadě jde nejspíše o faunu svrchní křídy (turon-maastricht).

Z hlediska palynologie byly všechny vzorky na palynomorfy zcela sterilní. $V$ reziduu sedimentu nebyla po maceraci patrná téměř žádná organická hmota, která se projevuje tmavou barvou tohoto zbytku. Palynologie tedy bohužel nemůže pro sledované sedimenty poskytnout žádné výsledky.

\section{Průsvitné těžké minerály}

Pro vzorky je typické velké zastoupení zirko$\mathrm{nu}$ (přesahující $20 \%$ ) s převažujícím zastoupením oválných zrn indikujících delší transport a patrně i několikanásobnou redepozici. $Z$ dalších minerálů je důležité vysoké zastoupení kyanitu (19-54 \%), rutilu a turmalínu, které jsou zastoupeny $6-8 \%$. U části vzorků je významněji zastoupen i silimanit ( 9 a 27 \%). (obr. 9, Elektronická př́loha C). Různě zastoupené jsou i minerály skupiny amfibolů ( 1-30\%), které jsou charakteristické výraznou korozí zrn.

\section{Diskuze a závěr}

\section{Vývoj depozičního prostředí}

Neogenní sedimenty odráží transport k S-SZ, tedy směrem k současnému údolí Loučky, př́ípadně do údolí Svratky. Oblast mezi Tišnovem a Boračí, podobně jako oblast mezi Tišnovem a Lomnicí, je známa výskytem sladkovodních ottnangských a především marinních badenských sedimentů. Tvorba hlubokých depresí, dnes v terénu představovaných údolími výše jmenovaných vodních toků, př́padně i vyklízení výplně ze zdrojových oblastí těchto depresí, mohly vést $\mathrm{k}$ tvorbě paleoreliéfu, vhodného pro sedimentaci aluviálně-fluviálních sedimentů zastižených na lokalitě Předklášteří.

Iniciální stadium sedimentace neogenních sedimentů představované FA1 lze spojit s vyplňováním nejhlubší deprese v terénu a proximálními částmi depozičního prostř̌edí. V místech s největším sklonem reliéfu došlo $\mathrm{k}$ určité stabilizaci ř́čnního koryta a relativně rychlému vyplňování deprese poměrně hrubozrnnými sedimenty. Ríční koryto bylo relativně hluboké (několik m) s depozicí rozsáhlých komplexních/složených fluviálních valů.

$\mathrm{V}$ již více zarovnaném paleoreliéfu docházelo následně k sedimentaci FA2. Sedimentace tohoto typu však mohla laterálně doprovázet/navazovat na sedimentaci FA1 a sedimenty FA2 pak představují distálnější partie tohoto depozičního prostředí. Lze předpokládat relativně plochý aluviální kužel, jenž byl protkán několika hlavními distribučními koryty, která však byla relativně mělká a jejichž hloubku lze dle mocnosti facie Gm odhadnout max. do $1 \mathrm{~m}$. Dominantní sedimentace byla nejspíše ve formě štítových tokủ/plošného splachu, které mohly vznikat při prèlití mělkých koryt výše v proximálnější části kužele, př́ípadně střední části kužele (koryta představovaná facií $\mathrm{Gm}$ ). Sedimenty střední části kužele byly protkány množstvím drobných plochých koryt nižšího řádu hlubokých max. první decimetry. 
Celkově lze především v rámci FA2, ale i FA1 předpokládat vysokou úroveň mobility fluviálních koryt, což může odrážet vysoký poměr transportovaného materiálu vůči průtočnému množství a absenci stabilních břehů koryt tvořených jílovitými kohezivními sedimenty (Hassan 2005), které by typicky odpovídaly mimobřežním sedimentům. Absence významnějšího výskytu mimokorytových sedimentů demonstruje vysoce mobilní charakter koryt i redepozici sedimentů fluviálních koryt (Steel a Thompson 1983). Společně tato data ukazují na oblast relativně proximalní ke zdroji, přebytek materiálu k transportu, pravidelný a opakovaně vysoký průtok, což umožňovalo akumulaci laterálně a vertikálně amalgamovaných výplní koryt i relativně hrubozrnnější sedimentaci na tělese aluviálního kužele.

Sedimenty faciální asociace 2 jsou erozně seříznuty a následně překryty kvartérními sedimenty aluviálního kužele, tj. FA3. Erozní báze těchto sedimentů i směr jejich transportu ukazují na změnu paleosklonu reliéfu v zájmové oblasti, když tento je pro sedimenty FA3 nastaven směrem k SV-V. Pro sedimentaci FA3 lze předpokládat vyšší roli subaerických podmínek než v př́padě FA1 a FA2.

\section{Chemická variabilita sedimenti̊}

Chemické složení studovaných sedimentů vykazuje, pokud jde o tvar křivky REE, značné podobnosti s granodiority brněnského masivu (obr. 7c; PGB) a spodnobadenským jílem. Většina prvků s malou mobilitou během zvětrávání (Ti, Hf, Zr) se svými obsahy blíží složení PGB (obr. 7c). To naznačuje, že studované sedimenty vznikly zvětráváním granitoidních hornin. Nízké obsahy Tb, $\mathrm{Nb}, \mathrm{Hf}, \mathrm{Zr}$ a REE ve vzorku sedimentu ze Svinošic dobře korelují se složením hornin v jejich podloží (hlavně gabra a diority). Obsahy těchto prvků jsou ve zmíněných horninách nižší (Hanžl et al. 2019; Tb < 0,2 ppm, $\mathrm{Nb}<3,4$ ppm, $\mathrm{Hf}<2,3$ ppm, Zr 1,8-93,4 ppm, suma REE 3,3-81,1 ppm). Nízké obsahy $R b, U$, Th ve vzorku sedimentu ze Svinošic mohou souviset $\mathrm{s}$ charakterem protolitu, ale nemůžeme vyloučit také vliv zvětrávání a diageneze. Na základě zjištěných údajů předpokládáme, že protolitem pro vznik sedimentu ze Svinošic byly hlavně horniny dioritové subzóny brněnského masivu. Nemůžeme však také vyloučit, že se zde lokální materiál mísil se zvětralinami z granitoidů (např́klad relativně vysoké obsahy REE). V trojúhelníkovém diagramu K/100-Ba- $100{ }^{\star} \mathrm{Cs}$ jsou studované vzorky distribuovány podél spojnice mezi PGB a jílem (obr. 7b), což může naznačovat, že obsahy LIL prvků (large-ion lithophile elements) jsou výrazně ovlivněny variabilitou v obsazích živců a jílových minerálů (nejvyšší obsah živců je v PGB, zatímco nejvyšší obsah jílových minerálů je v neogenním jílu). Studované sedimenty tedy s největší pravděpodobností vznikly zvětráváním hornin brněnského masivu. Variabilita obsahů $\mathrm{CaO}$ v těchto sedimentech pravděpodobné souvisí s postdiagenetickým odvápněním některých jílů.

Chemické složení studovaných vzorků je podobné chemickému složení sedimentů miocenního stáří z lokality Kohoutovice (Tomanová Petrová et al. 2018). Oba vzorky jílů z Kohoutovic normalizované PGB se však od studovaných vzorků odlišují pozitivní Zr, Hf anomálií. Poměrně vysoké obsahy Zr a Hf, které dobře korelují s vysokými obsahy HREE, naznačují vazbu zmíněných stopových prvků na ultrastabilní těžké minerály jako je zirkon. Poměrně vysoké jsou také obsahy $\mathrm{TiO}_{2}$, což naznačuje vyšší stupeň zvětrávání ve srovnání s ostatními studovanými sedimenty (Tomanová Petrová et al. 2018). Zvýšenými obsahy $\mathrm{Fe}_{2} \mathrm{O}_{3}$ a $\mathrm{Cr}_{2} \mathrm{O}_{3}$ ve vzorcích $\mathrm{z}$ lokality Kohoutovice mohou souviset s príměsí bazických a ultrabazických hornin, které vystupují v podloží. Podíl tohoto materiálu je však malý, protože zjištěné složení jílových minerálů (Tomanová Petrová et al. 2018) dobře odpovídá zvětralinám derivovaným $\mathrm{z}$ granodioritů v podmínkách semiaridního až humidního klimatu (např. Deepthy a Balakrishnan 2005).

Celkově tedy můžeme říci, že všechny studované sedimenty, včetně dvou dříve popsaných vzorků z Kohoutovic, vznikaly $\mathrm{v}$ podobných podmínkách. Jedná se o zvětraliny derivované $\mathrm{z}$ vyvřelých hornin brněnského masivu. Zvětralý materiál měl většinou lokální zdroj (transport maximálně na vzdálenost prvních kilometrů).

\section{Těžké minerály}

Analýza průsvitných těžkých minerálů byla použita především jako pomocná metoda pro stratigrafické zařazení. Při interpretaci je možné se do určité míry opřít o výsledky analýz asociací PTM z krasových dutin na Květnici a na Čebínce (Otava 2000), které mají mnohem blíže k cenomanským sedimentům v. okraje České kř́idové tabule, popř. k rudickým vrstvám v Moravském krasu, než k badenským pískům z širšího okolí Tišnova, které jsou lokálně rovněž tvořené redeponovaným materiálem z cenomanských písků a pískovců. Za typomorfní asociaci minerálů rudických vrstev a cenomanu považuje Otava (2000) skupinu turmalín, kyanit, staurolit a rutil, zatímco v sedimentech spodního badenu se objevují vyšší podíly granátu a staurolitu. Analyzované sedimenty ze svrchní části lomu v Předklášteří ale mají oproti sedimentům $\mathrm{z}$ krasových dutin spíše obrácený podíl zirkonu a kyanitu, což nabízí prostor pro alternativní úvahy, nicméně bez srovnávacího materiálu je interpretace jen těžko možná. Každopádně je ale možné říci, že sedimenty nad zvětralými horninami brunovistulika jsou vzhledem k minimálnímu zastoupení granátu stáří nejméně spodnomiocénního, ale nedá se vyloučit i stáří větší.

Jako zdrojové oblasti jsou vcelku nepřekvapivě předpokládány poměrně blízké regionální jednotky: svratecké krystalinikum (kyanit, turmalín), moldanubikum (silimanit), př́ípadně i olešnická skupina moravika (kyanit).

\section{Paleontologie}

Obdobná foraminiferová fauna jako na lokalitě Předklášteří je součástí pseudoasociace $\mathrm{z}$ písků v Lomnici u Tišnova (např. pískovna v Dřevařských závodech, MB003/24-143 (nepublikováno). Písky z Lomnice jsou pravděpodobně badenské. Velice podobná fauna byla rovněž zjištěna $\mathrm{v}$ jemnozrnných prachovitých píscích z vrtů J-106 a J-108 z Bělče (Bubík 1997) patrně stejného stáří jako písky z Lomnice, ačkoli pro to nejsou př́mé 
biostratigrafické důkazy. Obdobná foraminiferová fauna se vyskytuje v lakustrinních a brakických faciích ottnangu v Brně a okolí. Ačkoli mezi různými uvedenými výskyty existují určité rozdíly ve složení aglutinované fauny, jednotícím prvkem je hojný výskyt úlomků Rhizammina a výskyt druhů Karrerulina conversa, Spiroplectammina navarroana, Haplophragmoides spp. aj.

Ačkoli pseudoasociace z Lomnice a Bělče obsahují některé faunistické prvky běžné ve svrchní křídě české křídové pánve, obsahují rovněž i druhy spíše s tethydní afinitou. $\mathrm{V}$ prrípadě asociací $\mathrm{z}$ oblasti Brna je to ještě markantnější a zdroj redepozic je nutno hledat nejspíše v dnes již zcela denudovaných čelních šupinách ždánické jednotky. Provenience faun není zatím uspokojivě dořešena.

\section{Poděkování}

Tento př́spěvek byl vytvořen $v$ rámci interního projektu č. 321070, který je součástí DKRVO/ČGS (2018-2022), Oblast výzkumu 5: Výzkum geologických rizik a č. 321180, Oblast výzkumu 1: Výzkum stavby a vývoje zemské kưry. Autoři děkují editorovi doc. Mgr. Martinovi Ivanovovi, Dr., za podnětné připomínky. Dík rovněž patří vedení společnosti KÁMEN Zbraslav, a.s. - kamenolomu v Předklášteří, za umožnění provádění našich prací v objektu lomu.

\section{Literatura}

Allen, J. R. L. (1983). Studies in fluviatile sedimentation: bars, bar complexes and sandstone sheets (low-sinuosity braided streams) in the Brownstones (Lower Devonian), Welsh Borders. - Sedimentary Geology, 33, 237-293.

Allen, J. P., Fielding, C. R., Rygel, M. C., Gibling, M. R. (2013). Deconvolving signals of tectonic and climatic controls from continental basins: an example from the Late Paleozoic Cumberland Basin, Atlantic Canada. - Journal of Sedimentary Research, 83, 847-872.

Ashley, G. M. (1990). Classification of large-scale subaqueous bedforms: a new look at an old problem. - Journal of Sedimentary Petrology, 60, 160-172.

Blikra, L. H., Nemec, W. (1998). Postglacial colluvium in western Norway: depositional processes, facies and palaeoclimatic record. - Sedimentology, 45, 909-959.

Boynton, W. V. (1984). Cosmochemistry of the rare earth elements: meteorite studies. - In: Henderson, P. (ed.): Rare Earth Element Geochemistry, 63-114. - Elsevier. Amsterdam.

Bridge, J. S. (1993). Description and interpretation of fluvial deposits: a critical perspective. - Sedimentology, 40, 801-810.

Bridge, J. S. (2003). Rivers and Floodplains. - Blackwell Scientific, Oxford. 504 pp.

Bristow, C. S. (1987): Brahmaputra River: channel migration and deposition. - In: Ethridge, F. G., Flores, R. M., Harvey, M. D. (eds): Recent Developments in Fluvial Sedimentology. - SEPM Special Publication, 39, 63-74.

Brzák, P. (2000). Spodnobadenské sedimenty a morfotektonický vývoj jv. okraje Českého masívu (jihozápadní Morava). - Scripta Facultatis Scientiarum Naturalium Universitatis Masarykianae Brunennsis, Geology, 30, 65-74.

Bubík, M. (1997). O miocénu z vrtů na trase vodovodního přivaděče Vír-Brno. - Zprávy o geologických výzkumech v roce 1996, 64-66.

Burda, J., Novotná, J. (2015). Rebilance zásob podzemních vod. Závěrečná zpráva průzkumného hydrogeologického vrtu 2242_2 Hradčany. Souhrnná dokumentace. - MS ČGS Praha.

Deepthy, R., Balakrishnan, S. (2005). Climate control on clay mineral formation: Evidence from weathering profiles developed on either side of the Western Ghats. - Journal of Earth System Science, 114, 5, 545-556.

Friend, P. F. (1983). Toward the field classification of alluvial architecture or sequence. - In: Gibling, M. R. (2006). Width and thickness of fluvial channel bodies and valley fills in the geological record: a literature compilation and classification. Journal of Sedimentay Research, 76, 731-770.

Grym, V., Žůrek, V. (1965). Průzkum kamene. Předklášteří. - MS ČGS Praha.

Gürtlerová, P. et al. (1997). Databáze analytických stanovení na mapách geochemické reaktivity hornin 1: 50 000. - Litogeochemická databáze České geologické služby, Praha.

Hanžl, P. (ed.), Buriánková, K., Čtyroká, J., Čurda, J., Gilíková, H., Gürtlerová, P., Kabátník, P., Kratochvílová, H., Manová, M., Maštera, L., Neudert, O., Otava, J., Petrová P., Šalanský, K., Šrámek, J., Švecová, J., Vít J., (2007a). Základní geologická mapa České republiky 1:25000 s Vysvětlivkami, list 24-321 Tišnov. 1-83. Česká geologická služba Praha.

Hanžl, P. (ed.), Buriánková, K., Čech, S., Čtyroká, J., Čurda, J., Gilíková, H., Hradecká, L., Hubatka, F., Janoušek, V., Kašpárek, M., Manová, M., Maštera, L., Otava, J., Petrová P., Šalanský, K., Šrámek, J., Vít J., (2007b). Základní geologická mapa České republiky 1 : 25000 s Vysvětlivkami, list 24-322 Blansko. 1-68. Česká geologická služba Praha.

Hanžl, P., Janoušek, V., Soejono, I., Buriánek, D., Svojtka, M., Hrdličková, K., Erban V., Pin C. (2019). The rise of the Brunovistulicum: age, geological, petrological and geochemical character of the Neoproterozoic magmatic rocks of the Central Basic Belt of the Brno Massif. - International Journal of Earth Sciences (Geol Rundsch), 108, 4, 1165-1199.

Hanžl, P. (ed.), Baldík, V., Bubík, M., Buriánek, D., Dolníček, Z., Dvořák, I., Fürychová, P., Havlín, A., Hrdličková, K., Kociánová, L., Konečný, F., Krejčí, O., Krejčí, Z., Krumlová, H., Kryštofová, E., Müller, P., Paleček, M., Pecina, V., Pecka, T., Poul, I., Rez, J., Skácelová, D., Skácelová, Z., Slobodník, M., Šrámek, J., Tomanová Petrová, P., Večeřa, J., Vít, J. (2020). Základní geologická mapa České republiky 1 : 25000 s Vysvětlivkami 24-324 Brno-sever. 1-152. Česká geologická služba, Praha.

Hassan, M. A. (2005). Characteristics of gravel bars in ephemeral streams. - Journal of Sedimentary Research, 75, $29-42$. 
Haszeldine, R. S. (1983). Fluvial bars reconstructed from deep, straight channel, Upper Carboniferous coalfield of northeast England. - Journal of Sedimentary Petrology, 53, 1233-1248.

Hein, F. J., Walker, R. G. (1977): Bar evolution and development of stratification in the gravelly, braided, Kicking Horse River, British Columbia. - Canadian Journal of Earth Sciences, 14, 562-570.

Hlavoňová, K. (1977). Miocénní sediment v oblasti mezi Moravskými Knínicemi a Lažánkami. - MS, diplomová práce, Katedra geologie a paleontologfie UJEP. Brno.

Janoušek, V., Farrow, C. M., Erban, V. (2006): Interpretation of whole-rock geochemical datain igneous geochemistry: Introducing Geochemical Data Toolkit (GCDkit). - Journal of Petrology, 47, 6, 1255-1259.

Jo, H. R., Chough, S. K. (2001). Architectural analysis of fluvial sequences in the northwestern part of Kyongsang Basin (Early Cretaceous), SE Korea. - Sedimentary Geology, 144, 307-334.

Lázničková, J., Pokorný, L. (2016). K. ú. Vohančice, parcela č. 278/1, vrtaná studna. Vyhledávání a průzkum zdroje podzemních vod pro obec Vohančice. - MS ČGS - Geofond Praha.

Lloret, J., Ronchi, A., López-Gómez, J., Gretter, N., de la Horra, R., Barrenechea, J. F., Arche A. (2018). Syn-tectonic sedimentary evolution of the continental late Palaeozoic-early Mesozoic Erill Castell-Estac Basin and its significance in the development of the central Pyrenees Basin. - Sedimentary Geology, 374, 134-157.

Lowe, D. R. (1982). Sediment gravity flows. II. Depositional models with special reference to the deposits of high-density currents. - Journal of Sedimentary Petrology, 52, 279-297.

Mackey, S. D., Bridge, J. S. (1995). Three dimensional model of alluvial stratigraphy: theory and application. - Journal of Sedimentary Research, B65, 7-31.

Miall, A. D. (1994). Reconstructing fluvial macroform architecture from two-dimensional outcrops: examples from the Castlegate Sandstone, Book Cliffs, Utah. - Journal of Sedimentary Research, B64, 146-158.

Miall, A. D. (1996). The Geology of Fluvial Deposits. SpringerVerlag, Berlin, Heidelberg, New York. 581 pp.

Musil, R. (1993). Geologický vývoj Moravy a Slezska v kvartéru. - In: Přichystal, A., Obstová, V., Suk, M. (eds): Geologie Moravy a Slezska. Sborník př́íspěvků k 90. Výročí narození prof. Dr. Karla Zapletala, 133-156, Moravské zemské Muzeum a Sekce geologických věd PřF MU, Brno.

Musil, R. (1997). Ende des Pliozän und unteres bis mittleres Pleistozän des Brünner Beckens. - Acta Musei Moraviae, Scientiae Geologicae, 81, 93-107, 1/2. Brno.

Nehyba, S., Bubík, M., Kirchner, K., Petrová, P., Vít, J. (2006). Fluviální sediment mezi Jinačovicemi a Kuřimí. - Geologické výzkumy na Moravě a ve Slezsku v roce 2005, 44-47. Brno.

Nemec, W., Kazanci, N. (1999). Quaternary colluvium in west-central Anatolia: sedimentary facies and palaeoclimatic significance. - Sedimentology, 46, 139-170.

Otava, J. (2000). Paleokrasové výplně typu rudických vrstev na Čebínce a na Květnici. - Geologické výzkumy na Moravě a ve Slezsku v r. 1999, 72-73, Brno.

Petrová, P., Vít, J., Čtyroká, J. (2001). Okrajové vývoje sedimentů karpatské předhlubně na listech map $1: 25000$ Blansko a Tišnov. - Scripta Facultatis Scientiarum Naturalium Universitatis Masarykianae Brunensis, Vol. 30, Geology. 55-64. Brno.

Rees, A. I. (1968). The production of preferred orientation in a concentrated dispersion of elongate and flattened grains. - Journal of Geology, 76, 457-465.

Rust, B. R. (1978). A classification of alluvial channel systems. - In: Miall, A. D. (ed.): Fluvial Sedimentology, Canadian Society Petroleum Geologists Memoir, 5, 187-198.

Schellmann, W. (1983). A new definition of laterite. - In: Hauser, G. (ed.): Natural Resources and Development, vol. 18. Metzingen, 7-21.

Scherer, C. M. S., Jardim de Sá, E. F., Córdoba, V. C., Sousa, D. C., Aquino, M. M., Cardoso, F. M. C. (2014). Tectono-stratigraphic evolution of the Upper Jurassic-Neocomian rift succession, Araripe Basin, Northeast Brazil. - Journal of South American Earth Sciences 49, 106-122.

Smetana, V. (1924). O kaolinu a uhlonosném miocénu se sladkovodní zvířenou od Lažánek poblíž Veverské Bítýšky na Moravě. - Sborník Státního ústavu geologického, 4, 289-301. Praha.

Steel, R. J., Thompson, D. B. (1983). Structures and textures in Triassic braided stream conglomerates ('Bunter' Pebble Beds) in the Sherwood Sandstone Group, North Staffordshire, England. - Sedimentology, 30, 341-367.

Šamalíková, M. (1992). Poznatky o geotechnickém charakteru hornin štolových úseků brněnského oblastního vodovodu v úseku Vír-Štěpánovice. - Geologický Průzkum, 10, 300-304.

Todd, S. P. (1996). Process deduction from fluvial sedimentary structures. - In: Carling, P. A., Dawson, M. R. (eds): Advances in Fluvial Dynamics and Stratigraphy, 299-350. Wiley, Chichester, UK.

Tomanová Petrová, P. (ed.), Baldík, V., Bubík, M., Buriánek, D., Franců, J., Fürychová, P., Gilíková, H., Havlín, A., Janderková, J., Kociánová, L., Kolejka, V., Konečný, F., Krejčí, O., Krejčí, V., Kryštofová, E., Kunceová, E., Otava, J., Paleček, M., Pecina, V., Pecka, T., Rez, J., Sedláček, J., Sedláčková, I., Skácelová, Z., Švábenická, L., Večeřa, J., Vít, J. (2013). Vysvětlivky k Základní geologické mapě České republiky 1: 25 000, list 24-431 Šlapanice. 216 s. - MS Archiv České geologické služby Praha.

Tomanová Petrová, P., Buriánek, D., Kirchner, K., Krejčí, O., Laufek, F., Nehyba, S. Otava, J. (2018). Pestré sedimenty ottnangu v Brně-Kohoutovicích. - Geologické výzkumy na Moravě a ve Slezsku 25, 1-2, 66-72.

Vít, J., Tomanová Petrová, P., Skácelová, Z., Hrutka, M. (2017). Geologická stavba hydrogeologického rajonu 2242 (Kuřimská kotlina) a představy vývoje toku řeky Svratky v kenozoiku. - Geoscience Research Reports, 50, 173-180.

Went, D. J. (2005). Pre-vegetation alluvial fan facies and processes: an example from the Cambro-Ordovician Rozel Conglomerate Formation, Jersey, Channel Islands. Sedimentology, 52, 693-713.

Wizevich, M. C. (1992). Sedimentology of Pennsylvanian quartzose sandstones of the Lee Formation, central Appalachian Basin: fluvial interpretation based on lateral profile analysis. - Sedimentary Geology, 78, 1-47. 